\title{
PENGARUH USABILITY, INFORMATION QUALITY, DAN INTERACTION QUALITY TERHADAP WEB REVISIT INTENTION DAN PURCHASE INTENTION WEBSITE BALI TOURISM BOARD
}

\author{
Hatane Semuel $^{{ }^{*} \text {, Serli Wijaya }}{ }^{2}$, Cristian Alianto ${ }^{3}$ \\ ${ }^{1,2}$ Fakultas Bisnis dan Ekonomi, Universitas Kristen Petra, Jl. Siwalankerto 121-131 Surabaya \\ ${ }^{3}$ Alumnus Magister Manajemen Fakultas Bisnis dan Ekonomi, Universitas Kristen Petra, Jl. Siwalankerto 121-131 Surabaya

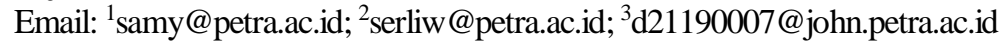 \\ *Penulis korespondens
}

\begin{abstract}
Abstrak: Penggunaan website untuk memasarkan produk pariwisata dikembangkan untuk kalangan usaha swasta maupun pemerintah. Website Bali Tourism Board merupakan salah satu website pemerintah provinsi Bali yang menawarkan berbagai produk wisata destinasi Bali. Untuk mengevaluasi efektivitas website ini, diperlukan penelitian ilmiah secara berkelanjutan terkait komunikasi pemasaran destinasi wisata Bali. Salah satu pengukuran yang dapat membantu mengevaluasi kualitas layanan website adalah melalui evaluasi terhadap peran dimensi webqual, usability, information quality dan interaction quality, sehingga dapat diketahui pengaruhnya terhadap web revisit intention dan purchase intention produk wisata Bali. Penelitian dilakukan melalui survey secara online terhadap 239 responden dengan menggunakan google form. Hasil penelitian menunjukan bahwa usability dapat berpengaruh langsung terhadap web revisit intention dan purchase intention, sedangkan information quality dan interaction quality tidak berpengaruh langsung terhadap purchase intention tetapi melalui web revisit intention, dan ditemukan bahwa revisit intention merupakan mediasi sempurna untuk pengaruh information quality dan interaction quality terhadap purchase intention, tetapi merupakan mediasi parsial pada pengaruh usability terhadap purchase intention.
\end{abstract}

Kata kunci: Usability; information; interaction; bali_tourism_board; intention; revisit; purchase.

Abstract: The use of websites to market tourism products is developed for private and government businesses. The Bali Tourism Board website is one of the websites of the Bali provincial government that offers various tourist products for Bali destinations. To evaluate the effectiveness of this website, continuous scientific research is needed related to marketing communications for Bali tourist destinations. One measure that can help evaluate the quality of website services is by evaluating the role of webqual dimensions, usability, information quality and interaction quality, so that the effects can be seen on web revisit intention and purchase intention of Bali tourism products. The research was conducted through an online survey of 239 respondents using google form. The results showed that usability can have a direct effect on web revisit intention and purchase intention, while information quality and interaction quality have no direct effect on purchase intention but through web revisit intention, and it was found that revisit intention is the perfect mediation for the influence of information quality and interaction quality on purchase intention, but it is a partial mediation on the effect of usability on purchase intention.

Keywords: usability; information; interaction; bali_tourism_board; intention; revisit; purchase.

\section{PENDAHULUAN}

Pengguna internet menurut Asosiasi Penyelenggara Jasa Internet Indonesia (APJII) naik sepanjang tahun mulai dari tahun 1998 ke 2018 bahkan sampai sekarang (APJII, 2018). Pertumbuhan pengguna internet di Indonesia berkembang pesat dibuktikan dari peningkatannya yang hanya 0,5 juta pada tahun 1998 , 25 juta pada tahun 2008, dan 171,17 juta pengguna pada tahun 2018 (APJII, 2018). Pertumbuhan pengguna ini juga mendukung penggunaan website di Indonesia serta memicu pemerintah untuk memanfaatkannya di berbagai sektor yang salah satunya adalah sektor pariwisata (Permadi, Soedijono \& Amborowati, 2015). E-Government merupakan salah satu instruksi presiden tentang penyelenggaraan pemerintahan daerah di Indonesia mengenai aplikasi website, diatur dengan Instruksi Presiden Republik Indonesia (Inpres) Nomor 3 Tahun 2003 tentang Kebijakan dan Strategi Nasional Pengembangan E-Government. Mengacu pada Inpres tersebut, maka perkembangan E-Government dengan menggunakan teknologi informasi dan komunikasi dalam pelayanan publik dan administrasi pemerintahan telah dilakukan oleh setiap daerah povinsi dan kabupaten kota di Indonesia. Salahsatu aplikasi E-Government adalah dalam bentuk website resmi pariwisata pemerintah daerah untuk pemasaran pariwisata dan kebudayaan daerah. Kegunaan website ini adalah sebagai media komunikasi pemasaran pariwisata dan kebudayaan daerah (Permadi et al, 2015). Jumlah wisatawan mancanegara (wisman) ke Indonesia mencapai 15.810 .305 orang pada tahun 2018, Jumlah sasaran kunjungan wisatawan mancanegara tahun 2019 adalah 20 juta, sedangkan wisata 
nusantara 275 juta. Wisatawan di zaman ini lebih sering menggunakan website untuk mendapatkan gambaran tempat wisata atau pemesanan tiket objek wisata, hotel, dan lainnya (Feng, Morrison, \& Ismail, 2003; Shi, 2006). Website telah memiliki peranan penting sebagai gerbang pertama wisatawan dan alat bantu berwisata domestik maupun internasional (Feng et al, 2003).

Website yang menyajikan informasi dan pelayanan yang memuaskan dapat mendorong purchase intention terhadap produk atau jasa (Jauhari, Kusumawati \& Nuralam, 2019). Webqual memiliki pengaruh terhadap purchase intention (Jauhari et al, 2019; Octavia \& Tamerlane, 2017; Tandon, Kiran \& Sah, 2017). Website dengan standar kualitas yang baik menjadi faktor yang sangat penting untuk persepsi pelanggan (Samudro \& Widyastuti, 2020). Standar kualitas website yang baik diukur menggunakan dimensi usability, information quality dan interaction quality (Goswami, S, 2013). Website yang berkualitas baik khususnya yang memberi keamanan dapat mengurangi risiko yang dirasakan pelanggan (Goswami, S, 2013).

Alasan mengapa penelitian ini perlu dilakukan karena masih terlihat ada kesenjangan konseptual (conceptual gap) dari beberapa hasil penelitian. Penelitian terdahulu menemukan webqual berpengaruh positif terhadap purchase intention (Jauhari et al, 2019; Octavia \& Tamerlane, 2017; Tandon et al, 2017), webqual tidak berpengaruh terhadap purchase intention (Coursaris, Van Osch \& Albini, 2018); (Perdana \& Suzianti, 2017), webqual berpengaruh negatif terhadap purchase intention (Batbayar, Batsaikhan, Enebish, Munkhazaya \& Sodnompil, 2018). Kesenjangan ini mendorong penelitian menguji pengaruh langsung webqual terhadap purchase intention ini perlu diuji pada objek wisata.

\section{TINJAUAN PUSTAKA}

\section{S-O-R Model}

Penelitian ini menggunakan teori utama (grand theory) yaitu S-O-R Model dan teori pendukung yaitu dimensi webqual, website revisit intention, dan purchase intention. S-O-R model diawali dengan adanya masalah pada penilaian sosial untuk menilai sikap dari individu. Konsep ini berkembang menjadi cara menentukan sikap dan implikasi pada pemrosesan informasi oleh pelanggan. Perkembangan berikutnya menyatakan jika ingin terlibat maka objek sosialnya harus di dalam ego subjek (Lastovicka, J. L. 1979). Akhirnya S-O-R model yang terdiri dari satu faktor eksternal yaitu stimulus (S) dan dua faktor internal yaitu organism $(\mathrm{O})$ dan response-oriented $(\mathrm{R})$.
Situational involvement pada website yaitu dimensi kualitas website yang dapat merangsang pelanggan berkeinginan menggunakan website.

Penelitian tentang minat menyatakan terdapat empat indikator yaitu minat transaksional, minat referensial, minat preferensial, dan minat eksploratif. Minat transaksional adalah kecenderungan membeli produk/jasa. Minat referensial adalah kecenderungan untuk mereferensikan produk/jasa ke orang lain (rekomendasi). Minat preferensial adalah kecenderungan untuk memilih produk dibandingkan produk lain. Minat eksploratif adalah kecenderungan pelanggan untuk mencari informasi produk yang diminati. Kualitas informasi menjadi sangat penting untuk mendorong niat pembelian.

Webqual adalah proses terstruktur yang menyediakan sebuah cara untuk mengidentifikasi Voice of Customer (VOC) melalui pengembangan dan implementasi produk atau jasa. Webqual mengalami perkembangan dari Webqual 1.0 menitikberatkan analisis kualitas informasi dan kekurangan pada interaksi kualitas layanan. Webqual 2.0 menekankan pada kualitas interaksi menghilangkan kualitas informasi dari Webqual 1.0. Webqual 3.0 membawa identifikasi tiga dimensi dari kualitas website yaitu kualitas website yaitu kemudahan, kualitas informasi, dan kualitas interaksi pelayanan.

Banyak peneliti telah mempelajari faktor penentu penggunaan situs web dalam penelitian bisnis. Namun keberhasilan implementasi teknologi internet ini sangat tergantung pada niat penggunaan secara berkelanjutan daripada penggunaan awal (Chen et al, 2010). Konsep niat mengunjungi kembali situs web (website revisit intention) masih menjadi perhatian penelitian managerial (Ku \& Chen, 2015). (Reynolds \& Ruiz de Maya, 2013) mengkonseptualisasikan niat mengunjungi kembali situs web sebagai kemungkinan pelanggan mengunjungi kembali situs web. Bukti kuat hubungan antara perilaku disengaja dan perilaku aktual dapat ditemukan dalam banyak penelitian (Karjaluoto \& Leppaniemi, 2013). Dengan demikian, studi niat mengunjungi kembali situs web dianggap masih perlu dikembangkan.

\section{Hubungan pengaruh antar konsep dan hipotesis penelitian}

Penelitian tentang masing-masing dimensi webqual terhadap purchase intention masih jarang dilakukan. Usability atau ease of use dalam online purchasing untuk tiket pesawat adalah tingkat pelanggan prospektif dapat membeli produk/jasa tanpa usaha berlebih. Penelitian ini juga mengatakan website design sebagai salah satu indikator usability 
juga berpengaruh pada purchase intention (Mohd Sam \& Tahir, 2009). Usability didefinisikan sebagai perasaan pada website tentang kemudahan dipelajari dan dioperasikan, kemudahan navigasi, mudah digunakan, dan mudah dimengerti (Barnes \& Vidgen, 2006). Penelitian pada air ticketing service di Mongolia menyatakan bahwa usability memiliki pengaruh positif, terhadap purchase intention (Batbayar et al, 2018). Penelitian pada e-commerce di Indonesia menyatakan bahwa website design tidak berpengaruh terhadap purchase intention (Kartavianus \& Napitupulu, 2012). Usability juga berpengaruh terhadap purchase intention pada pembelian tiket pesawat secara online dan online shopping di Malaysia serta mobile shopping di Taiwan (Chen, L. Y. 2013; Meskaran, Ismail \& Shanmugam, 2013; Mohd Sam \& Tahir, 2009; Tandon et al, 2017; Tarigan \& Jacqueline, 2018). Sehingga dapat dibuat hipotesis terkait dengan dimensi usability:

H1a: Terdapat pengaruh usability terhadap purchase intention

Information quality tidak berpengaruh terhadap purchase intention online shopping di Kunming (Yang, Baleanu \& Zhong, 2013), pada e-commerce di Indonesia juga tidak berpengaruh untuk generasi milenial (Kartavianus \& Napitupulu, 2012); Tarigan \& Jacqueline, 2018). Penelitian di Lazada Indonesia ditemukan bahwa information quality berpengaruh terhadap purchase intention. Pelanggan Lazada juga memiliki rasa perhatian dan keinginan untuk membeli produk setelah melihat informasi (Jauhari et al, 2019). Sehingga muncul hipotesis terkait dengan dimensi information quality, adalah:

H1b: Terdapat pengaruh information quality terhadap purchase intention

Interaction quality yaitu interactivity dan security memiliki pengaruh langsung ke purchase intention pada penelitian online shopping di Kunming (Yang, Baleanu \& Zhong, 2013), Ease of payment dan trust yang merupakan indikator dari interaction quality memiliki pengaruh terhadap purchase intention pada e-commerce di Indonesia (Yang, Baleanu \& Zhong, 2013). Penelitian ini didukung oleh (Kartavianus \& Napitupulu, 2012) pada e-commerce di Indonesia yang mengatakan hal yang sama. Pernyataan ini didukung oleh penelitian sebelumnya yang mengatakan e-commerce memang menekankan pada security dan ease of payment pada jasa online (Widyaningsih \& Suryani, 2018; Kartavianus \& Napitupulu, 2012). Sehingga muncul hipotesis terkait dengan dimensi interaction quality adalah:

H1c: Terdapat pengaruh interaction quality terhadap purchase intention.
Usability disebut system quality terdiri dari adaptability, availability, reliability, respond time. Usability dalam penelitian sistem kesehatan (Buletin Penelitian Sistem Kesehatan, (BPSK)) memiliki pengaruh positif terhadap intensitas kunjungan website (Widyaningsih \& Suryani, 2018). Kegunaan website yang semakin baik akan menaikkan intensitas pengguna mengunjungi website. Usability dapat memiliki pengaruh terhadap banyak variabel. Termasuk terhadap website revisit intention (Tandon et al, 2017). Sehingga muncul hipotesis terkait dengan dimensi usability:

H2a: Terdapat pengaruh usability terhadap website revisit intention

\section{Information quality terhadap website revisit intention}

Information quality biasa diukur dari informasi atau kualitas data yang didapat dalam website. Information quality berpengaruh signifikan terhadap intensitas kunjungan website dalam penelitian BPSK. Pernyataan ini berarti semakin baik information quality yang ditawarkan website menyebabkan pengguna website semakin sering menggunakan website (Widyaningsih \& Suryani, 2018). Information quality merupakan kualitas isi atau informasi yang ditawarkan website dimana dapat memiliki pengaruh terhadap intention. Sedangkan intention dapat dikembangkan lebih lagi ke arah website revisit intention. Penelitian yang dilakukan (Tandon et al, 2017) memiliki pengaruh signifikan terhadap website revisit intention. Sehingga muncul hipotesis terkait dengan dimensi information quality:

$\mathrm{H} 2 \mathrm{~b}$ : Terdapat pengaruh information quality terhadap website revisit intention

\section{Interaction quality terhadap website revisit intention}

Interaction quality berupa upaya pemenuhan kebutuhan konsumen dengan cara penyampaian yang tepat. Interaction quality yang baik memiliki pengaruh pada penelitian BPSK. Hasil penelitian menunjukkan bahwa semakin tinggi kualitas interaksi layanan website maka intensitas kunjungan website semakin meningkat (Widyaningsih \& Suryani, 2018). Interaction quality atau kemudahan penggunaan merupakan bagaimana website berinteraksi dengan mudah atau sulit terhadap pengguna. Interaction quality memiliki pengaruh terhadap. Intention dalam penelitian ini adalah website revisit intention (Tandon et al, 2017). Sehingga muncul hipotesis terkait dengan dimensi information quality:

$\mathrm{H} 2 \mathrm{c}$ : Terdapat pengaruh interaction quality terhadap website revisit intention 
Berdasarkan studi yang dilakukan oleh (Semuel, $\mathrm{H}, 2020$ ) ditemukan bahwa minat menggunakan situs web di kalangan milenial berdampak positif terhadap minat membeli produk batik tradisional Indonesia secara online. Selain itu, ditemukan juga bahwa minat untuk menggunakan situs web dapat berperan sebagai mediasi sempurna antara kualitas situs web terhadap kepentingan berperilaku (Semuel, H, 2020; Akram et al, 2018). Ketika konsumen memiliki niat/perhatian yang baik terhadap suatu website, akan ingin mencoba berbelanja melalui web. (Lee, Ahn, Kim \& Youn, 2014). Konsumen yang sering mengunjungi internet mal harus puas dengan kualitas website kemudian akan memiliki niat mengunjungi kembali (Jeon \& Kim, 2004; Lee, Kim, Lee \& Youn, 2012). Dengan demikian, studi preseden mengatakan bahwa frekuensi kunjungan kembali tinggi meningkatkan niat membeli (Lee, Ahn, Kim \& Youn, 2014). Berdasarkan uraian diatas maka hipotesis dapat dibangun sebagai berikut:

$\mathrm{H} 3$ : Website revisit intention berpengaruh terhadap purchase intention.

\section{Model Hipotesis Penelitian:}

Berdasarkan uraian hipotesis yang dikemukakan di atas, maka dapat digambarkan model hipotesis seperti Gambar 1.

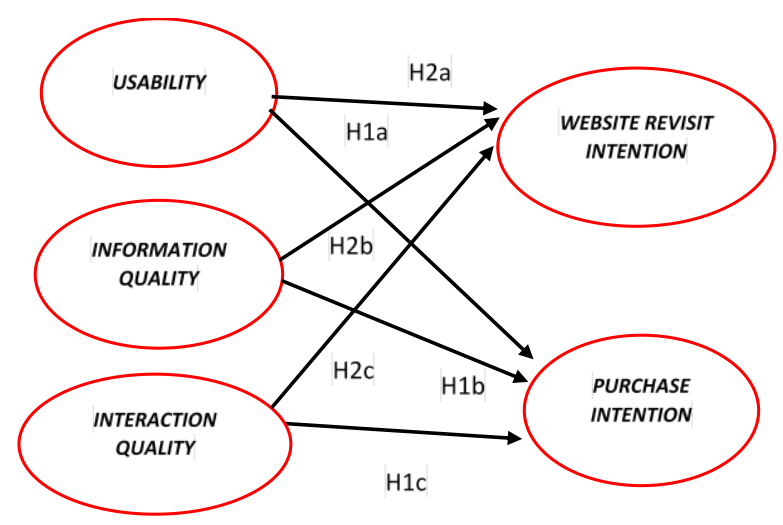

Gambar 1. Model Hipotesis Penelitian

\section{METODE PENELITIAN}

Penelitian dilakukan melalui tahapan-tahapan sistematis dan rincian penelitian yang jelas terkait pengambilan data sampai proses analisis dan penyajian informasi dari hasil penelitian. Rincian penelitian dapat membantu persiapan penelitian, pengambilan data, dan analisis data dan laporan hasil penelitian. Penelitian ini termasuk jenis penelitian deskriptif kausalistik untuk mengetahui hubungan antar dimensi webqual dengan website revisit intention dan purchase intention. Dilakukan dengan pendekatan penelitian kuantitatif.

\section{Populasi dan Sampel}

Populasi penelitian ini adalah pengguna internet yang pernah menggunakan layanan travel commerce yang berdomisili di Indonesia. Travel commerce yang dimaksud antara lain Traveloka, Agoda, Airbnb, Pegipegi, tiket.com, Airy, Trivago atau sejenisnya dalam setahun terakhir sebelum pandemic covid-19, dan pernah menjelajah (browsing) ke website Bali Tourism Board, atau yang bersedia menjelajah website Bali Tourism Board yang disediakan peneliti. Metode ini dilakukan kepada dua kelompok responden yaitu mahasiswa Universitas Kristen Petra Surabaya program Manajemen Pariwisata dan Manajemen Perhotelan karena kedua program ini lebih banyak terekspos dengan industri pariwisata dan perhotelan dan traveler yang pernah menggunakan website Bali Tourism Board. Jumlah sampel ditentukan berdasarkan jumlah indikator atau parameter dalam model, jumlah minimal dan maksimal yaitu 5-10 kali jumlah indikatornya (Hair, Sarstedt, Hopkins \& Kuppelwieser, 2014), berdasarkan pedoman tersebut, maka dalam penelitian ini diperoleh ukuran minimal sampel adalah 150 responden.

\section{Metode Pengumpulan Data}

Metode dan prosedur pengumpulan data ini mengikuti langkah-langkah berikut: pertama apakah calon responden apakah pernah menggunakan layanan travel commerce seperti Traveloka, Agoda, Airbnb, Pegipegi, tiket.com, Airy, Trivago atau sejenisnya dalam satu tahun terakhir sebelum covit-19. Langkah kedua peneliti menanyakan apakah calon responden pernah menggunakan website Bali Tourism Board jika ya, maka calon responden diminta mengisi kuesioner langsung, jika belum, maka peneliti meminta calon responden mencoba website Bali Tourism Board selama minimal lima menit, kemudian mengisi kuesioner. Kuesioner dirancang menjadi dua bagian yaitu terkait dengan profil responden, dan pernyataan indikator variabel penelitian dengan menggunakan skala likert 5 poin, yaitu: Sangat tidak setuju (STS=1), Tidak setuju ( $\mathrm{TS}=2)$, Netral $(\mathrm{N}=3)$, Setuju $(\mathrm{S}=4)$, Sangat setuju ( $\mathrm{SS}=5$ )

\section{Definisi Operasional Variabel}

\section{Dimensi Webqual}

a. Usability Usability adalah kualitas yang berkaitan dengan website seperti penampilan, kemudahan penggunaan, navigasi, dan tampilan kepada pelanggan (Barnes \& Vidgen, 2006). Indikator empiris dari usability adalah sebagai berikut: 
(1) Kemudahan mencari informasi, (2) Daya tarik tampilan website (3) Penyampaian pengetahuan produk/jasa (4) Pemberian pengalaman positif menjelajah (browsing) (5) Penampilan menu pilihan produk pariwisata jelas.

b. Information Quality

Information quality adalah kualitas isi website, kesesuaian informasi untuk keperluan pelanggan seperti akurasi, format, dan relevansi (Barnes \& Vidgen, 2006; Suhendra, E. S, 2009). Indikator empiris information quality adalah: (1) Keakuratan informasi (2) Tingkat kepercayaan informasi (3) Kemutakhiran informasi (4) Relevansi informasi dengan kebutuhan (5) Kemudahan pemahaman informasi

c. Interaction Quality

Interaction quality adalah kualitas yang dialami pelanggan saat mempelajari lebih dalam website pada kepercayaan dan empati (Barnes \& Vidgen, 2006; Suhendra, E. S, 2009). Indikator empiris dari interaction quality adalah sebagai berikut: (1) Tingkat reputasi (2) Rasa aman untuk memasukkan data pribadi (3) Produk/ jasa sesuai selera pribadi (4) Kemudahan untuk berkomunikasi (feedback) (5) Keyakinan akan produk/jasa yang ditawarkan

\section{Purchase intention}

Purchase intention adalah situasi seseorang sebelum melakukan sesuatu untuk memprediksi tindakan atau perilaku untuk membeli dalam suatu kondisi (Setyawan \& Ihwan, 2004). Indikator purchase intention dibuat dengan menyeleksi dari beberapa penelitian sebagai berikut (Pappas, $\mathrm{N}$, 2016; Pramono \& Ferdinand, 2012): (1) Minat bertransaksi membeli produk pariwisata (2) Minat merekomendasikan ke orang lain (3) Minat menjadikan destinasi Bali sebagai pilihan utama (4) Minat mencari informasi untuk membeli produk pariwisata (5) Secara umum berminat untuk mengunjungi destinasi wisata Bali.

\section{Website revisit intention}

Website revisit intention dalam penelitian ini mengacu kepada keinginan untuk mengunjungi kembali website Bali Tourism Board, dengan indicator pengukurannya adalah: (1) Keinginan mengunjungi untuk mendapatkan informasi kekinian (2) Keinginan mengunjungi untuk berinteraksi (3) Keinginan mengunjungi kembali untuk melihat informasi terkini (4) Secara umum berkeinginan kembali mengunjungi website wisata Bali.

\section{Metode Analisis}

Analisis yang dilakukan terbagi atas dua bagian termasuk dengan uji validitas dan reliabilitas instrument penelitian, yaitu: 1) Analisis deskriptif yang dibantu dengan software SPSS dan 2) Analisis Structural Equation Model (SEM), yang akan dibantu dengan software SMARTH PLS

\section{ANALISIS DAN PEMBAHASAN}

\section{Profil Responden}

Data penelitian diperoleh melalui pengisian kuesioner online yang tersedia di formulir Google dengan Jumlah responden yang terlibat dalam penelitian ini adalah 239 orang yang terdiri dari 150 mahasiswa Fakultas Bisnis dan Ekonomi Universitas Kristen Petra, dan 89 traveler yang telah menggunakan website Bali Tourism Board dan sering menggunakan paling sedikit satu dari layanan travel commerce seperti Traveloka, Agoda, Airbnb, Pegipegi, tiket.com, Airy, Trivago atau sejenisnya dalam satu tahun terakhir sebelum covit-19. Data menunjukkan bahwa 36\% (86 orang) adalah laki-laki dan 64\% (153 orang) adalah perempuan. Berdasarkan frekuensi penggunaan internet dalam sehari terdapat 39\% sangat sering (> enam jam per hari), sedangkan 47,6\% (dua jam sampai empat jam sehari), jarang 13,4\% (satu jam - dua jam sehari). Untuk kategori mahasiswa dapat diketahui bahwa responden yang sering melakukan aktivitas internet dalam sehari, 54,7\% (> 4 jam) sangat sering, $42,7 \%$ sedang ( 2 jam -4 jam) dan 2,7\% jarang $(<2$ jam). Untuk kelompok traveler terlihat sebanyak $14,6 \%$ (> 4 jam) sangat sering, 55,2\% sedang ( 2 jam 4 jam) dan 30,2\% jarang $(<2$ jam $)$. Dari tujuan penggunaan internet $64,2 \%$ untuk kegiatan yang berhubungan dengan aktivitas utama (belajar atau pekerjaan) dan 35,8\% untuk kegiatan lainnya termasuk kegiatan bersenang-senang.

\section{Analisis Indikator Variabel Website Quality}

Data penelitian ini diperoleh melalui pengisian kuesioner online tersedia di google form yang diedarkan pada 5 November 2020 sampai dengan 20 Desember 2020 dengan jumlah responden seperti yang terjelaskan di atas. Berikut ini adalah deskripsi dari mean, standar deviasi dan loading factor indicator dari dimensi website quality (Webqual) seperti pada Tabel 1.

Deskripsi indicator Usability pada Tabel-1, memperlihatkan bahwa pada umumnya kinerja dari semua indicator sudah dapat dikatakan baik dengan nilai $M$ lebih besar dari empat $(M>4$, $S D<1)$, dan variasi yang rendah, kecuali yang terkait dengan pernyataan penampilan menu pilihan produk pariwisata jelas $(M=3,95 ; S D=0,866)$. Hal ini menunjukan bahwa website Bali Tourism Board belum mampu 
Tabel-1 Analisis Indikator Webqual

\begin{tabular}{|c|c|c|c|c|}
\hline Indikator Webqual & \multicolumn{3}{|c|}{ Mean Std. Deviation loading factors } & Cronbach's Alpha \\
\hline \multicolumn{5}{|c|}{ Usability } \\
\hline Kemudahan mencari informasi & 4,12 & 0,849 & 0.814 & \\
\hline Daya tarik tampilan website & 4,39 & 0,837 & 0.788 & \\
\hline Penyampaian pengetahuan produk/jasa & 4,25 & 0,759 & 0.831 & 0,946 \\
\hline Pemberian pengalaman positif menjelajah & 4,22 & 0,827 & 0.782 & \\
\hline Penampilan menu pilihan produk pariwisata jelas & 3,95 & 0,866 & 0.711 & \\
\hline \multicolumn{5}{|c|}{ Information Quality } \\
\hline Keakuratan informasi yang disajikan & 3,95 & 0,866 & 0.635 & \\
\hline Tingkat kepercayaan informasi yang tinggi & 4,06 & 0,843 & 0.823 & \\
\hline Memiliki kemutakhiran informasi & 4,15 & 0,882 & 0.790 & 0,945 \\
\hline Relevansi informasi dengan kebutuhan & 4,22 & 0,863 & 0.714 & \\
\hline Memiliki kemudahan pemahaman informasi & 4,27 & 0,863 & 0,648 & \\
\hline \multicolumn{5}{|c|}{ Interaction Quality } \\
\hline Interaksi dengan website Bali memiliki reputasi & 4,25 & 0,841 & 0.809 & \\
\hline Rasa aman untuk memasukkan data pribadi pada website Bali & 4,28 & 0,845 & 0.819 & \\
\hline Produk/jasa sesuai selera pribadi & 3,87 & 0,905 & 0.790 & 0,947 \\
\hline Memiliki kemudahan berkomunikasi & 3,94 & 0,966 & 0.826 & \\
\hline Keyakinan akan produk/jasa yang ditawarkan & 4,07 & 0,925 & 0.705 & \\
\hline
\end{tabular}

menyajikan kualitas website yang memudahkan pengunjung mendapatkan produk yang ditawarkan dengan jelas. Pada variable ini terlihat bahwa indicator yang menjelaskan tentang pengetahuan produk dan jasa yang ditawarkan cukup baik $(\mathrm{M}=4,25 ; \mathrm{SD}=$ $0,759)$ dengan factor loading tertinggi 0,831. Berdasarkan factor loading dari semua indicator dengan koefisien lebih besar dari 0,7 dan nilai crombach alpha $=0,946$ menunjukan bahwa indicator yang digunakan dalam mengukur variabel usability telah memiliki validitas dan reliabilitas yang memadai.

Selanjutnya terkait dengan deskripsi indicator Information Quality pada Tabel-1, memperlihatkan bahwa sama seperti variable usability terlihat bahwa pada umumnya kinerja dari semua sudah dapat dikatakan baik dengan nilai $\mathrm{M}$ lebih besar dari empat ( $\mathrm{M}>4$, SD <1), dan variasi yang rendah, kecuali yang terkait dengan pernyataan "keakuratan informasi yang disajikan" ( $\mathrm{M}=3,95 ; \mathrm{SD}=0,866)$. Hal ini menunjukan bahwa website Bali Tourism Board menyajikan informasi memiliki kualitas informasi yang dipersepsikan kurang akurat. Pengunjung biasanya mengkonfirmasi informasi terkait dengan penyajian informasi terkait objek wisata yang diinginkan dari sumber-sumber lainnya, sehingga dapat memberikan penilaian terhadap informasi tersebut. Pada variable ini terlihat bahwa indicator yang menjelaskan tentang "tingkat kepercayaan informasi yang tinggi" (M=4,06; $S D=$ 0,843 ) dengan factor loading tertinggi 0,823 . Berdasarkan factor loading terlihat ada dua indicator dengan koefisien kurang dari 0,7, namun nilai koefisien crombach alpha $=0,945$ menunjukan bahwa indicator yang digunakan dalam mengukur variabel usability telah memiliki validitas yang cukup dan reliabilitas yang memadai. Salah satu indicator yang memiliki validitas yang cukup namun memiliki nilai mean yang tertinggi adalah "memiliki kemudahan pemahaman informasi" ( $\mathrm{M}=4,27 ; \mathrm{SD}=0,863)$ dengan koefisien factor loading $=0,648$. Hal ini dapat saja terjadi karena pengunjung menganggap bahwa kemudahan pemahaman informasi merupakan sesuatu yang wajar harus diutamakan dalam menyajikan kualitas informasi online, sehingga hal itu tidak kuat untuk menggambarkan kualitas informasi secara keseluruhan.

Deskripsi terkait dengan indicator Interaction Quality pada Tabel-1, memperlihatkan bahwa dari lima indicator terdapat tiga indicator yang dapat dikatakan telah memiliki kinerja baik dengan nilai mean lebih besar dari empat $(\mathrm{M}>4$, SD $<1)$, dan SD kecil menunjukan variasi yang rendah, yaitu terkait dengan pernyataan (1) Interaksi dengan website Bali memiliki reputasi $(\mathrm{M}=4,25 ; \mathrm{SD}=0,925)$. Sedangkan indicator yang memiliki kinerja cukup terkait dengan pernyataan (1) Produk/jasa sesuai selera pribadi $(\mathrm{M}=3,87 ; \mathrm{SD}=0,905)$ dan (2) Memiliki kemudahan berkomunikasi $(\mathrm{M}=3,94 ; \mathrm{SD}=0,966)$. Hal ini menunjukan bahwa website Bali Tourism Board menyajikan fasilitas interaksi dengan pelanggan terkait produk dan jasa terlihat belum banyak bervariasi sehingga kurang memenuhi beberapa pengunjung, juga terkait dengan interaksi dalam berkomunikasi masih terlihat dari sisi pengunjung belum memiliki kemudahan aksesnya. Hal yang perlu juga diperhatikan adalah terkait dengan kualitas interaksi menyangkut kemudahan berkomunikasi, karena memiliki factor loading dengan koefisien 
terbesar 0,826. Validitas dan reliabilitas pengukuran variable ini telah memenuhi dilihat dari koefisien factor loading telah lebih besar dari 0,7, dan koefisien crombach alpha $=0,947$.

\section{Analisis Indikator Variabel Web Revisit Intention dan Purchase Intention}

Deskripsi indicator Web Revisit Intention pada Tabel-2, memperlihatkan bahwa terdapat empat indikator yang digunakan untuk mengukur variable ini. Kinerja dari empat indicator ini terlihat ada dua indicator yang dapat dikatakan baik dengan nilai $\mathrm{M}$ lebih besar dari empat $(M>4, S D<1)$, dan variasi yang rendah, yaitu yang terkait dengan pernyataan (1) Ingin mengunjungi web lagi untuk berinteraksi $(M=4,05$; $\mathrm{SD}=0,922)$, dan (2) Ingin kunjungi web lagi untuk melihat informasi terkini $(\mathrm{M}=4,15 ; \mathrm{SD}=0,961)$. Hal ini menunjukan bahwa keinginan untuk mendapatkan informasi terkini dan tujuan berinteraksi menjadi prioritas pengunjung untuk mengunjungi kembali website Bali Tourism Board. Jika dikaitkan dengan variable webqual, maka terlihat bahwa pendorong untuk berkunjung ini belum optimal dilakukan oleh website Bali Tourism Board, walaupun kinerja kedua indicator ini sudah baik. Sedangkan untuk dua indicator lainnya adalah (1) Ingin kunjungi web lagi karena kemudah digunakan ( $\mathrm{M}=3,97: \mathrm{SD}=0,923)$, dan (2) Secara umum ingin mengunjungi website Bali Tourism Board ( $\mathrm{M}=3,98 ; \mathrm{SD}=1,008)$, persepsi beberapa pengguna untuk enggan mengunjungi kembali website Bali Tourism Board karena tidak mudah digunakan dan ini perlu diperhatikan karena koefisien factor loading indicator terbesar kedua yaitu 0,804, sehingga cukup menggambarkan variable web revisit intention. Pada variable ini terlihat bahwa indicator yang menjelaskan tentang pengetahuan produk dan jasa yang ditawarkan cukup baik $(\mathrm{M}=4,25 ; \mathrm{SD}=$ 0,759 ) dengan factor loading tertinggi 0,837 . Berdasarkan factor loading dari indicator "Ingin kunjungi web lagi untuk melihat informasi terkini" memiliki koefisien kurang dari 0,7 yaitu 0,610 sehingga memiliki nilai validitas yang cukup, sedangkan tiga indicator yang lain telah memiliki koefisien factor loading lebih besar dari 0,7 serta nilai koefisien crombach alpha $=0,884$ menunjukan bahwa indicator yang digunakan dalam mengukur variabel web revisit intention telah memiliki validitas dan reliabilitas yang memadai.

Seperti variabel Web Revisit Intention pada Tabel-2, berikut analisis terhadap variable purchase intention. Tabel-2 memperlihatkan bahwa terdapat lima indikator yang digunakan untuk mengukur variable ini. Kinerja dari lima indicator ini terlihat ada dua indicator yang dapat dikatakan kinerjanya baik dengan nilai $M$ lebih besar dari empat $(M>4, S D<1)$, dan variasi yang rendah, yaitu yang terkait dengan pernyataan (1) Berminat merekomendasikan produk wisata Bali ke orang lain ( $M=4,14 ; \mathrm{SD}=0,906)$, dan (2) Berminat membeli produk wisata Bali $(\mathrm{M}=4,36$; $\mathrm{SD}=0,887)$. Hal ini menunjukan bahwa kebanyakan pengunjung website Bali Tourism Board berkeinginan untuk merekomendasikan dan juga berkeinginan untuk membeli produk wisata Bali. Selain itu ada tiga indicator yang memiliki kinerja cukup, yaitu: (1) Berminat menjadikan destinasi Bali sebagai pilihan utama (M=3,59: $\mathrm{SD}=1,037)$, (2) Berminat melakukan transaksi pembelian produk wisata di website Bali $(\mathrm{M}=3,65 ; \mathrm{SD}=1,071)$, dan (3) Secara umum berminat mengunjungi destinasi wisata Bali $(\mathrm{M}=3,90$; $\mathrm{SD}=1,034)$. Dari hasil ini maka perlu diperhatikan bahwa pengunjung website Bali belum berminat menjadikan Bali sebagai pilihan utama destinasi yang akan dikunjungi.

Tabel 2. Analisis Indikator Web Revisit Intention dan Purchase Intention

\begin{tabular}{|c|c|c|c|c|}
\hline $\begin{array}{l}\text { Indicators Revisit } \\
\quad \text { Intention \& } \\
\text { Purchase Intention }\end{array}$ & Mean & $\begin{array}{c}\text { Std. } \\
\text { Deviation }\end{array}$ & $\begin{array}{l}\text { Factor } \\
\text { Loading }\end{array}$ & $\begin{array}{c}\text { Cronbach's } \\
\text { Alpha }\end{array}$ \\
\hline \multicolumn{5}{|c|}{ Revisit Intention } \\
\hline $\begin{array}{l}\text { Ingin kunjungi web } \\
\text { lagi karena mudah } \\
\text { digunakan }\end{array}$ & 3,97 & 0,923 & 0.804 & \multirow{4}{*}{0,884} \\
\hline $\begin{array}{l}\text { Ingin mengunjungi } \\
\text { web lagi untuk } \\
\text { berinteraksi }\end{array}$ & 4,05 & 0,922 & 0.837 & \\
\hline $\begin{array}{l}\text { Ingin kunjungi web } \\
\text { lagi untuk melihat } \\
\text { informasi terkini }\end{array}$ & 4,15 & 0,961 & 0.610 & \\
\hline $\begin{array}{l}\text { Secara umum ingin } \\
\text { mengunjungi } \\
\text { website wisata Bali }\end{array}$ & 3,98 & 1,008 & 0.714 & \\
\hline \multicolumn{5}{|c|}{ Purchase Intention } \\
\hline $\begin{array}{l}\text { Berminat menjadikan } \\
\text { destinasi Bali seba- } \\
\text { gai pilihan utama }\end{array}$ & 3,59 & 1,037 & 0.814 & \multirow{5}{*}{0,87} \\
\hline $\begin{array}{l}\text { Berminat melakukan } \\
\text { transaksi pembelian } \\
\text { produk pariwisata } \\
\text { di website Bali }\end{array}$ & 3,65 & 1,071 & 0.788 & \\
\hline $\begin{array}{l}\text { Berminat mereko- } \\
\text { mendasikan produk } \\
\text { wisata Bali ke } \\
\text { orang lain }\end{array}$ & 4,14 & 0,906 & 0.831 & \\
\hline $\begin{array}{l}\text { Berminat untuk mem- } \\
\text { beli produk wisata }\end{array}$ & 4,36 & 0,887 & 0.782 & \\
\hline $\begin{array}{l}\text { Secara umum ber- } \\
\text { minat mengunjungi } \\
\text { destinasi wisata Bali }\end{array}$ & 3,90 & 1,034 & 0.711 & \\
\hline
\end{tabular}


Hal ini karena koefisien factor loading merupakan terbesar kedua yaitu 0,814, sehingga cukup menggambarkan variable purchase intention. Indicator yang terlihat memiliki factor loading tertinggi 0,831 adalah pernyataan "Berminat merekomendasikan produk wisata Bali ke orang lain". Berdasarkan factor loading dari setiap indicator yang memiliki koefisien lebih dari 0,7 serta nilai koefisien crombach alpha $=$ 0,87 menunjukan bahwa indicator yang digunakan dalam mengukur variabel purchase intention telah memiliki validitas dan reliabilitas yang memadai.

\section{Analisis pengaruh antar variabel dan pengujian hipotesis}

Hasil pengolahan data menggunakan PLS sebagai salah satu program profesional untuk mengolah data dalam bentuk SEM (Structural Equation Modeling) menunjukkan bahwa terdapat beberapa hubungan antar variable dalam model yang berpengaruh signifikan dan beberapa lagi tidak berpengaruh. Berdasarkan Tabel-3, dapat terlihat bahwa dimensi webqual yang dalam model ini dilakukan sebagai variable independen memiliki perilaku dalam model sebagai berikut:

Usability memiliki pengaruh langsung secara positif signifikan pada web revisit intention ( $\mathrm{sig}=$ 0,000 ) dan juga berpengaruh langsung secara positif signifikan (sig. = terhadap purchase intention. Berdasarkan pembahasan sebelumnya terkait dengan indicator yang memiliki indicator factor loading terbesar maka dapat diartikan bahwa kemudahan penggunaan website yang terkait dengan pemberi pengetahuan pengunjung yang makin baik akan berpengaruh positif terhadap keinginan mengunjungi web lagi untuk berinteraksi, dan juga mendorong pengunjung untuk berminat merekomendasikan produk wisata Bali ke orang lain.

Information quality tidak memiliki pengaruh (sig. $=0.991$ ) langsung kepada purchase intention, namun memiliki pengaruh langsung secara positif signifikan (sig. 0,042) terhadap web revisit intention. Berdasarkan pembahasan sebelumnya memberikan makna bahwa ketika pengunjung memiliki tingkat kepercayaan informasi yang tinggi pada website, maka akan berpengaruh positif terhadap keinginan mengunjungi web lagi untuk berinteraksi.

Interaction quality tidak memiliki pengaruh langsung terhadap purchase intention (sig. $=0,763$ ) namun memiliki pengaruh langsung secara positif signifikan terhadap web revisit intention (sig $=0,000)$. Memiliki makna bahwa ketika pengunjung merasa dalam berinteraksi dengan website dapat memiliki kemudahan berkomunikasi tidak dapat mendorongnya untuk berminat merekomendasikan produk wisata Bali kepada orang lain, namun dapat mendorongnya untuk berkeinginan mengunjungi kembali website untuk berinteraksi dengan fasilitas yang ada di website.

Web revisit intention memiliki pengaruh positif signifikan berpengaruh positif signifikan (sig. $=0,000$ ) terhadap purchase intention. Hal ini memberikan gambaran bahwa ketika pengunjung website berkeinginan mengunjungi kembali website untuk berinteraksi dengan fasilitas yang ada di website, maka akan mendorongnya untuk berminat merekomendasikan kepada orang lain. Dari hasil analisis sebelumnya dapat disimpulkan bahwa Web revisit intention berperan sebagai mediasi sempurna antara pengaruh Information quality terhadap purchase intention dan juga antara pengaruh Interaction quality terhadap purchase intention. Selain itu Web revisit intention berperan sebagai mediasi parsial antara pengaruh usability terhadap purchase intention.

Berdasarkan informasi dari Tabel-3, dapat dibuat persamaan path regresi sebagai berikut:

Web rev-inten. $=0,496 * *$ usability $+0,086 *$ infor -

quality $+0,354 *$ inter-quality; $\mathrm{R}^{2}=0,619$

Purch_inten. $=0,202^{*}$ usability $+0,001$ infor-quality $+0,020$ inter-quality $+0,570^{* *}$ Web rev-inten.; $\mathrm{R}^{2}=0,556$

Berdasarkan nilai R2 dari dua persamaan di atas, dapat ditentukan koefisien prediktif relevans dari model ini adalah:

$Q^{2}=1-(1-0,619)(1-0,556)=0,831$

Angka koefisien $\mathrm{Q}^{2}$ menunjukkan bahwa kemampuan untuk memprediksi purchase intention dari dimensi webqual usability, information quality, interaction quality dan web revisit intention adalah sebesar $83,1 \%$ dari dalam model. Artinya model ini dapat dikembangkan untuk menganalisis perilaku purchase intention pengunjung Website Bali Tourism Board Hasil

Pengujian hipotesis dengan kriteria penerimaan didasarkan pada $\mathrm{p}$ value dari koefisien regresi masingmasing variabel, Jika $p$ value $<0,05$, maka hipotesis penelitian diterima, dan berlaku sebaliknya, jika $p$ value $\geq 0,05$ maka hipotesis ditolak. 
Tabel-3. Pengaruh Antar Variabel dan Pengujian Hipotesis

\begin{tabular}{|c|c|c|c|c|}
\hline $\begin{array}{c}\text { Hubungan } \\
\text { Pengaruh Antar } \\
\text { Variabel }\end{array}$ & $\begin{array}{l}\text { Original } \\
\text { Sample } \\
(O)\end{array}$ & $\begin{array}{l}\text { Standard } \\
\text { Deviation } \\
\text { (STDEV) }\end{array}$ & $\begin{array}{c}t \text {-Stat } \\
(|O / S T D E V|)\end{array}$ & $\begin{array}{c}P \\
\text { Values }\end{array}$ \\
\hline $\begin{array}{l}\text { Information } \\
\text { Quality -> } \\
\text { Purchase Intention }\end{array}$ & 0,001 & 0,051 & 0,011 & 0,991 \\
\hline $\begin{array}{l}\text { Information } \\
\text { Quality -> Web } \\
\text { Revisit Intention }\end{array}$ & 0,086 & 0,042 & 2,040 & 0,042 \\
\hline $\begin{array}{l}\text { Interaction Quality } \\
\text {-> Purchase } \\
\text { Intention }\end{array}$ & 0,020 & 0,066 & 0,302 & 0,763 \\
\hline $\begin{array}{l}\text { Interaction Quality } \\
\text {-> Web Revisit } \\
\text { Intention }\end{array}$ & 0,354 & 0,060 & 5,925 & 0,000 \\
\hline $\begin{array}{l}\text { Usability -> } \\
\text { Purchase Intention }\end{array}$ & 0,202 & 0,085 & 2,386 & 0,017 \\
\hline $\begin{array}{l}\text { Usability -> Web } \\
\text { Revisit Intention }\end{array}$ & 0,496 & 0,066 & 7,465 & 0,000 \\
\hline $\begin{array}{l}\text { Web Revisit } \\
\text { Intention -> } \\
\text { Purchase Intention }\end{array}$ & 0,570 & 0,066 & 8,642 & 0,000 \\
\hline
\end{tabular}

Berdasarkan Tabel 3 maka hasil pengujian hipotesis penelitian ini adalah sebagai berikut:

H1a: Terdapat pengaruh usability terhadap purchase intention diterima

H1b: Terdapat pengaruh information quality terhadap purchase intention ditolak

H1b: Terdapat pengaruh interaction quality terhadap purchase intention ditolak

H2a: Terdapat pengaruh usability terhadap web revisit intention diterima

H1b: Terdapat pengaruh information quality terhadap web revisit intention diterima

H1b: Terdapat pengaruh interaction quality terhadap web revisit intention diterima

H3: Terdapat pengaruh web revisit intention terhadap purchase intention diterima

\section{Ujii Fit Model}

Salah satu bagian yang perlu dilakukan untuk menunjukan bahwa model ini dapat menyajikan informasi yang valid dan reliabel, maka perlu dilakukan beberapa uji statistik yang dapat membantu melihat kesesuaian model yang digunakan. Berikut beberapa uji tersebut:

\section{Uji Reliabilitas dan Validitas Model}

Ukuran reliabilitas konstruk variable dalam model dapat dilihat pada beberapa indicator koefisien Cronbach's Alpha, rho A, Composite Reliability, dan Average Variance Extracted. Beberapa indicator ini memberikan makna yang sama atas konstruk model ini reliabel jika (1) koefisien Cronbach's Alpha > 0,70; koefisien rho A > 0,70; Composite Reliability > 0,80; dan koefisien AVE > 0,50. Data yang dimunculkan pada Tabel-4, menunjukan bahwa semua syarat telah terpenuhi. Hal ini menunjukan bahwa model ini memuat semua variable yang pengukurannya memiliki reliabilitas yang sesuai.

Tabel 4. Indikator Uji Reliabilitas Konstruk Variabel

\begin{tabular}{lcccc}
\hline $\begin{array}{l}\text { Konstruk } \\
\text { Variabel }\end{array}$ & $\begin{array}{c}\text { Cronbach's } \\
\text { Alpha }\end{array}$ & rho_A & $\begin{array}{c}\text { Composite Average Variance } \\
\text { Reliability }\end{array}$ & Extracted(AVE) \\
\hline $\begin{array}{l}\text { Information } \\
\begin{array}{l}\text { Quality } \\
\text { Interaction }\end{array}\end{array}$ & 0.733 & 0.727 & 0.831 & 0.554 \\
$\begin{array}{l}\text { Quality } \\
\text { Purchase }\end{array}$ & 0.854 & 0.874 & 0.893 & 0.626 \\
$\begin{array}{l}\text { Intention } \\
\text { Usability }\end{array}$ & 0.845 & 0.851 & 0.888 & 0.615 \\
$\begin{array}{l}\text { Web Revisit } \\
\text { Intention }\end{array}$ & 0.732 & 0.756 & 0.890 & 0.618 \\
\hline
\end{tabular}

Selanjutnya untuk mengevaluasi apakah indikator-indikator yang digunakan untuk mengukur konstruk variable di dalam model, salah satunya dapat dilihat dari indicator discriminant validity seperti pada Tabel-5. Kriteria validitas instrument pengukuran variable melalui indicator akan dievaluasi berdasarkan koefisien diskriminasi antar variable dalam model. Jika ternyata koefisien yang dimiliki antar sesama variable lebih tinggi dibandingkan dengan antar variable lainnya, maka dapat disimpulkan indikator pengukur variable dalam model memiliki validasi yang sesuai. Jika ternyata ada yang tidak memenuhi maka uji ini gagal untuk mengetahui validitas konstruk variabelnya. Informasi Tabel-5 menunjukan koefisien diagonalnya telah memenuhi persyaratan yang dimaksud (angka yang dicetak tebal), sehingga dapat disimpulkan konstruk variable dalam model telah memiliki validasi yang sesuai.

Tabel-5. Koefisien Discriminant Validity Konstruk Variabel

\begin{tabular}{|c|c|c|c|c|c|}
\hline $\begin{array}{c}\text { Konstruk } \\
\text { Variabel }\end{array}$ & $\begin{array}{c}\text { Informa- } \\
\text { tion } \\
\text { Quality }\end{array}$ & $\begin{array}{l}\text { Interac- } \\
\text { tion } \\
\text { Quality }\end{array}$ & $\begin{array}{l}\text { Purchase } \\
\text { Intention }\end{array}$ & Usability & $\begin{array}{c}\text { Web } \\
\text { Revisit } \\
\text { Intention }\end{array}$ \\
\hline $\begin{array}{l}\text { Web Revisit } \\
\text { Intention }\end{array}$ & 0.173 & 0.681 & 0.732 & 0.731 & 0.746 \\
\hline Usability & 0.097 & 0.641 & 0.632 & 0.786 & \\
\hline $\begin{array}{l}\text { Purchase } \\
\text { Intention }\end{array}$ & 0.121 & 0.538 & 0.784 & & \\
\hline $\begin{array}{l}\text { Interaction } \\
\text { Quality }\end{array}$ & 0.110 & 0.791 & & & \\
\hline $\begin{array}{l}\text { Information } \\
\text { Quality }\end{array}$ & 0.744 & & & & \\
\hline
\end{tabular}

\section{SIMPULAN DAN REKOMENDASI}

Dari hasil analisis dan pembahasan yang dilakukan dapat simpulan yang dibuat adalah sebagai berikut: terdapat beberapa temuan yang menjelaskan bahwa information quality dan interaction quality 
tidak memiliki pengaruh langsung terhadap purchase intention tetapi membutuhkan pendalaman secara berulang dengan cara mengunjungi kembali website terutama dalam hal melakukan interaksi dengan fasilitas website. Agak berbeda dengan usability yang ternyata berpengaruh langsung terhadap purchase intention. Hal ini tentu terkait dengan perilaku pembelian online yang mengutamakan kepercayaan, yang dapat diuji dengan kemudahan menggunakan fasilitas websitenya. Simpulan lainnya bahwa model penelitian ini telah memiliki validitas dan reliabilitas yang memenuhi secara statistik dan juga memiliki nilai prediksi relevansi yang tinggi.

Beberapa rekomendasi yang dapat diberikan dalam penelitian ini terkait dengan pengelola website Bali Tourism Board bahwa perlu ada perbaikan layanan untuk menaikan kinerja beberapa indicator dari dimensi webqual yang terlihat masih rendah tetapi mampu menggambarkan variable yang diukur, misalnya pada indicator penampilan menu pilihan produk pariwisata jelas pada variable usability, indicator keakuratan informasi yang disajikan pada variable information quality, indicator produk/jasa sesuai yang disajikan sesuai selera pribadi pengunjung, maksudnya harus lebih beragam, serta indicator kemudahan berinteraksi keduanya dari variable interaction quality. Hal ini kemudian akan meningkatkan web revisit intention dan secara simultan berpengaruh kepada purchase intention.

\section{DAFTAR PUSTAKA}

Akram, U., Hui, P., Khan, M. K., Tanveer, Y., Mehmood, K., \& Ahmad, W. (2018). How website quality affects online impulse buying: Moderating effects of sales promotion and credit card use. Asia Pacific Journal of Marketing and Logistics, 30(1), 235-256. https://doi.org/10.1108/APJML -04-2017-0073

Barnes, S. J., \& Vidgen, R. T. (2006). Data triangulation and web quality metrics: A case study in egovernment. Information \& Management, 43(6), 767-777.

Batbayar, M., Batsaikhan, B., Enebish, G., Munkhzaya, U., \& Sodnompil, N. (2018). Influences of Website Quality on Online Purchase Intention of Air Ticketing Service: In case of Mongolia. Invention Journal of Research Technology in Engineering \& Management (IJRTEM) Www. Ijrtem.Com, 2(6), 13-18.

Chen, L. Y. (2013). The quality of mobile shopping system and its impact on purchase intention and performance. International Journal of Managing Information Technology (IJMIT), 5(2), 23-32.
Chen, M. T., Lu, M. P., Wu, Y. J., Song, J., Lee, C. Y., Lu, M. Y. \& Chen, L. J. (2010). Near UV LEDs made with in situ doped pn homojunction $\mathrm{ZnO}$ nanowire arrays. Nano letters, 10(11), 43874393.

Coursaris, C. K., Van Osch, W., \& Albini, A. (2018). Antecedents and consequents of information usefulness in user-generated online reviews: A multi-group moderation analysis of review valence. AIS Transactions on Human-Computer Interaction, 10(1), 1-25.

Feng, R., Morrison, A. M., \& Ismail, J. A. (2003). East versus west: A comparison of online destination marketing in China and the USA. Journal of Vacation Marketing, 10(1), 43-56.

Goswami, S. (2013). Measuring customer satisfaction on webqual dimension for online banking: An empirical study. Paradigm, 17(1-2), 25-36.

Hair Jr, J. F., Sarstedt, M., Hopkins, L., \& Kuppelwieser, V. G. (2014). Partial least squares structural equation modeling (PLS-SEM). European business review.

Jauhari, M. T., Kusumawati, A., \& Nuralam, I. P. (2019). The Impact of Website Quality on Consumer Satisfaction and Purchase Intention (Study Case of E-Commerce Lazada Indonesia in Malang City). Jurnal Administrasi Bisnis, 67(1), 54-61.

Jeon, Dal-yeong, \& Kim, Chan-ho (2004). A Comparative Study of Influencing Factors on Shopping Satisfaction and Repeat Purchase Intention Between Internet Shopping Mall Types. Journal of Global Scholars of Marketing Science, $13,1-27$.

Karjaluoto, H., \& Leppaniemi, M. (2013). Social identity for teenagers: Understanding behavioral intention to participate in virtual world environment. Journal of theoretical and applied electronic commerce research, 8(1), 1-16

Kartavianus, O., \& Napitupulu, T. A. (2012). Determining factors on purchasing decision through ecommerce: A structural equations modelling framework. Procedia Engineering, (50), 463473.

Ku, E. C., \& Chen, C. D. (2015). Cultivating travellers' revisit intention to e-tourism service: the moderating effect of website interactivity. Behaviour \& Information Technology, 34(5), 465-478.

Lastovicka, J. L. (1979). Questioning the concept of involvement defined product classes. ACR North American Advances.

Lee, K. K., Ahn, S. H., Kim, H. D., \& Youn, M. K. (2014). Effects of the flow of an internet shopping mall upon revisit intention and purchase intention. The Journal of Business Economics and Environmental Studies, 4(4), 27-38. 
Lee, W. H., Kim, S. O., Lee, S.Y., \& Youn, M. K. (2012). Study on the Effects of Shop Choice Properties on Brand Attitudes: Focus on Six Major Coffee Shop Brands. Journal of Distribution Science, 10(3), 51-62.

Meskaran, F., Ismail, Z., \& Shanmugam, B. (2013). Online purchase intention: Effects of trust and security perception. Australian journal of basic and applied sciences, 7(6), 307-315.

Mohd Sam, M. F., \& Tahir, M. N. H. (2009). Website quality and consumer online purchase intention of air ticket. International Journal of Basic \& Applied Sciences, 9(10).

Octavia, D., \& Tamerlane, A. (2017). The influence of website quality on online purchase intentions on Agoda. com with e-trust as a mediator. Binus Business Review, 8(1), 9-14.

Pappas, N. (2016). Marketing strategies, perceived risks, and consumer trust in online buying behaviour. Journal of Retailing and Consumer Services, 29, 92-103.

Perdana, R. A., \& Suzianti, A. (2017, March). Analysis of usability factors affecting purchase intention in online e-commerce sites. In IOP Conference Series: Materials Science and Engineering (Vol. 185, No. 1, p. 012015). IOP Publishing.

Permadi, G., Soedijono, B., \& Amborowati, A. (2015). Pengukuran Mutu Website Dinas Pariwisata Pacitan Menggunakan Metode Webqual. Jurnal Informa, 1(1), 11-17

Pramono, R. \& Ferdinand, A. T. (2012). Analisis pengaruh harga kompetitif, desain produk, dan layanan purna jual terhadap minat beli konsumen sepeda motor Yamaha. Diponegoro Business Review, 1, 1-9.]

Reynolds, N., \& Ruiz de Maya, S. (2013). The impact of complexity and perceived difficulty on consumer revisit intentions. Journal of Marketing Management, 29(5-6), 625-645.

Samudro, D. A., \& Widyastuti, W. (2020). Peran Kualitas Layanan Elektronik, Presepsi Kemudahan, dan Kualitas Informasi terhadap Niat Pembelian Online Streaming Musik Spotify. Jurnal Ilmu Manajemen, 8(3), 968-980.

Semuel, H. (2020). Online Consumer Analysis of Indonesian Traditional Batik Products. Jurnal Manajemen dan Kewirausahaan, 22(1), 11-20.

Setyawan \& Ihwan. (2004). Pengaruh service quality perception terhadap purchase intentions: Studi empirik pada konsumen supermarket. Usahawan, 7, 29-37.

Shi, Y. (2006). The accessibility of Queensland visitor information centres' websites. Tourism Management, 27(5), 829-841.

Suhendra, E. S. (2009). Faktor determinan manajemen kualitas pada situs perpustakaan. Jurnal Ekonomi Bisnis, 14(3), 200-207.

Tandon, U., Kiran, R., \& Sah, A. (2017). Analyzing customer satisfaction: users perspective towards online shopping. Nankai Business Review International.

Tarigan, R. S. \& Jacqueline. (2018). Millennials' purchase intention towards online travel agent in Indonesia. Petra IJBS, 1(1), 23-34.

Widyaningsih, N. M., \& Suryani, E. (2018). Analisis Kepuasan Pengguna Website Jurnal Online dengan Menggunakan Metode Webqual (Studi Kasus Buletin Penelitian Sistem Kesehatan). Teknikom: Teknologi Informasi, Ilmu Komputer dan Manajemen, 2(1), 1-5.

Yang, X. J., Baleanu, D., \& Zhong, W. P. (2013). Approximate solutions for diffusion equations on Cantor space-time. Proceedings of the Romanian Academy A, 14(2), 127-133. 